\title{
The Impact of Interaction between Timing of Feedback Provision in Distance E-Learning and Learning Styles on achieving Learning Outcomes among Arab Open University Students
}

\author{
Mohammed Kamal Afify ${ }^{1 *}$ \\ ${ }^{1}$ Department of Educational Technology, College of Education, Imam Abdulrahman Bin Faisal University, SAUDI ARABIA
}

Received 3 December 2017 • Revised 3 April 2018 - Accepted 9 May 2018

\begin{abstract}
The present study aims to identify the impact of interaction between timing of providing feedback and technologies delivered in E-Learning environments (Immediate - Delayed) \& interaction with learning style (Active - Reflective) on developing the design and production skills of educational e-blogging; and satisfaction with e-learning environment. The sample consisted of (67) students from the Arab Open University, Kingdom of Saudi Arabia, Dammam Branch. The participants were divided into four experimental groups according to the design Factorial $(2 \times 2)$ : Group 1: (19) students with active learning style provided with immediate feedback; Group 2: (17) students with active learning style provided with delayed feedback; Group 3: (15) reflective students provided with immediate feedback; Group 4: (16) reflective students provided with delayed feedback. The tools include observation card, satisfaction scale with e-learning environment and learning style scale. The results showed statistically significant differences between the mean scores of the experimental groups, which received immediate feedback in acquiring the design and production skills of blogging and satisfaction with e-learning environment. The results also showed that students with active learning style were superior in their performance on each of the performance practical skills for the design and production of blogs and satisfaction with e-learning environment.
\end{abstract}

Keywords: learning style, e-learning platform, mobile learning (m- Learning), Imam Abdulrahman Bin Faisal University

\section{INTRODUCTION}

In the light of the rapid development of e-learning and distance education, a lot of universities across the world provide their courses and programs on the internet or in blended E-learning style. The number of students learning those courses around the world is in rapid increase, although there are different levels and types of E-learning. Most of studies confirmed that it's necessary to consider the quality of learning method and its effectiveness. The courses quality is an important key to achieve effective learning in e-learning environment $(\mathrm{Xu}, 2010)$.

The learner needs guidance and immediate feedback during and after the study, and the effectiveness of elearning increases through providing an immediate feedback which provides the learner with a lot of experience and helps improve his/her cognitive skills. Feedbacks enable the learner to participate and lead an effective discussion with their teachers and colleges, without feedback styles the e-learning design will become just plans to broadcast specific contents (Afifi, 2014).

The effective feedback of the evaluated formation plays a basic role in motivating students properly in elearning environment. Sorensen (2008) suggested to make the feedback a part and parcel of the design processes of e-learning and evaluation because it encourages students to participate and strengthen their independence. Previous studies confirmed that designing new perfect strategies to provide effective feedback of e-learning

(C) 2018 by the authors; licensee Modestum Ltd., UK. This article is an open access article distributed under the terms and conditions of the Creative Commons Attribution License (http://creativecommons.org/licenses/by/4.0/). $\square$ mafify@iau.edu.sa (*Correspondence) 


\section{Contribution of this paper to the literature}

- This study revealing the impact of interaction between timing feedback provision (immediate - delayed) and learning style (active - reflective). Students who received immediate feedback across M-learning environment techniques acquiring skills of the design of E-blogging and satisfaction about E-learning environment compared to the Students which received delayed feedback across learning management System (LMS).

- Active style students prefer learning through experimentation and team work, which made them achieve to better results in each of the practical performance of the design and production skills of e-blogging and satisfaction with e-learning environments, from those students who tends to abstract thinking, which Received delayed feedback type that provided to them across asynchronous blog in LMS.

- We believe the employing M-learning environments as effective tools for feedback provision as using smart personal cell phones to deliver feedbacks for students from a distance and fast reply to their tasks contribution in improving the quality of feedback and its impact on learning as well as achieving satisfaction through E-learning from a distance.

environment requires doing experimental research to specify which strategic factor of feedback agrees with learners and the necessary procedures for effective learning with feedback (Freney \& Wood, 2008; Narciss, 2013; Narciss et al., 2014; Vandewaetere, Desmet, \& Clarebout, 2011).

Evans and Waring (2004) found that students with specific learning styles may respond more to other different feedback types, or may prefer other feedback types which help them improve their acknowledgement (Evans \& Waring, 2011).

The study attempt to benefit from employment of levels of timing feedback provision by presentation timing varieties in the e-learning course that presented to learners through different platforms (immediate across mobile learning "google+ platform", delayed across learning management system "Moodle") to determine which levels are more effective.

\section{OBJECTIVES}

Revealing the impact of interaction between timing feedback provision (immediate across mobile-learning environment "google+ platform" and delayed across learning management system "Moodle", which are more suitable for the two dimensions of learning styles (active - reflective) by its significant impact on acquiring the skills of designing E-blogging and satisfaction with E-learning environment.

\section{SIGNIFICANCE}

- Qualify the teachers who teach the courses electronically and the designer of learning environment with the best feedback design types and the appropriate time of its provision.

- Guide the students towards timing feedback provision which suitable to his learning style to contribute in raising his performance standard and achieve satisfaction with e-learning environment.

- Direct the E-learning designers concern to the necessity of providing different electronic feedback types in E-learning environment to confront the individual differences among learners.

- The study considered as a part of doing more interaction between treatment and preparations, since it aims to provide education agreed with personal abilities and characteristics.

\section{QUESTIONS}

1. What is the impact of different timing feedback provision (Immediate - delayed) on (A- acquisition of the design and production skills of E-blogging, and B- satisfaction with E-learning environment)?

2. What is the impact of learning styles difference (active - reflective) on (A- acquisition of the design and production skills of E-blogging, and B- satisfaction with E-learning environment)?

3. What is the impact of the interaction between timing feedback provision (immediate -delayed), and learning style (active - reflective) on (A- acquisition of the design and production skills of E-blogging, and Bsatisfaction with E-learning environment)? 


\section{HYPOTHESES}

1. There is a statistically significant difference at level (0.05) between the mean scores of the experimental group students in their performance on the scale estimate for practical performance of the design and production skills of E-blogging due to the different timing feedback provision (Immediate - delayed).

2. There is a statistically significant difference at level (0.05) between the mean scores of the student with active learning style and the reflective students in their performance on practical scale estimate of the design and production skills of E-blogging.

3. There is a statistically significant difference at level (0.05) between the mean scores of the experimental groups students in their practical performance for the production and design skills of E- blogs due to the impact of interaction between timing feedback provision (immediate - delayed) and learning style (active reflective).

4. There is a statistically significant difference at level (0.05) between the mean scores of the experimental groups students in their performance on satisfaction scale with E-learning environment due to different timing feedback provision (immediate - delayed).

5. There is a statistically significant difference at level (0.05) between the mean scores of the experimental groups students with active learning style and the reflective students in their performance on satisfaction scale of E-learning environment.

6. There is a statistically significant difference at level (0.05) between the mean scores of the experimental groups students in their performance on satisfaction scale about E-learning environment due to the impact of interaction between timing feedback provision (Immediate - Delayed) and learning style (Active Reflective).

\section{LIMITATIONS}

For the purpose of the current research is limited to:

- Arab Open University students associated with general Diploma program in education and the whole registered to study educational technology course (Ed, 433).

- Two types of timing feedback provision (immediate - delayed)

- Active Learning style versus the reflective according to Felder - Silverman learning styles model without other learning styles.

\section{METHODOLOGY AND PROCEDURES}

The author utilized the experimental method to study the impact of different timing feedback provision and its delivery techniques in different E-learning environment (immediate across techniques of M-learning environment "google+ platform", delayed across techniques of E-learning management system "Moodle") on each of: the design and production skills for E-blogging and satisfaction with E-learning environment; and interaction with learning style (active - reflective).

\section{VARIABLES}

Independent variable: feedback provision styles: (Immediate feedback across techniques of M-learning environment; and Delayed feedback across techniques of learning management system "Moodle".

Classified variable: the current research included classified variable which is the leaning style: Active style versus reflective style.

Dependent variables: (The design and production of skills E-blogging; and Satisfaction with E-learning environment.

\section{THE EXPERIMENTAL DESIGN OF THE RESEARCH}

The experimental design depends on the factorial design $(2 * 2)$, which concerns with measuring the impact of two independent variables, and for each variable two levels at the same time (Khamis, 2013). Consequently, there are four experimental groups (Figure 1). 


\begin{tabular}{cl|l|l} 
& \multicolumn{3}{c}{ Timing feedback provision and delivery techniques } \\
& & \multicolumn{3}{c}{\begin{tabular}{l} 
in two different distance E-learning environment \\
\cline { 2 - 3 }
\end{tabular}} & $\begin{array}{l}\text { Immediate using M-learning } \\
\text { "google+ platform" }\end{array}$ & $\begin{array}{l}\text { Delayed feedback using learning } \\
\text { management system "Moodle" }\end{array}$ \\
\cline { 2 - 4 } $\begin{array}{c}\text { Learning } \\
\text { Style }\end{array}$ & Active & $\begin{array}{l}\text { Group (1); NO=19 } \\
\text { Active students provided by } \\
\text { immediate feedback }\end{array}$ & $\begin{array}{l}\text { Group (2); NO=17 } \\
\text { Active students provided by } \\
\text { delayed feedback }\end{array}$ \\
\cline { 2 - 4 } & Reflective & $\begin{array}{l}\text { Group (3); NO=15 } \\
\text { Reflective students provided } \\
\text { by immediate feedback }\end{array}$ & $\begin{array}{l}\text { Group (4); NO=16 } \\
\text { Reflective students provided by } \\
\text { delayed feedback }\end{array}$ \\
\hline
\end{tabular}

Figure 1. Experimental design research

\section{SAMPLE}

Arab Open University students of KSA Dammam branch, enrolled in Educational Technology course, 2nd semester of 2013 / 2014. The sample consisted of (67) students with age average (27.03), standard deviation (3.56), classified of two experimental groups according to experimental design and research variables.

\section{PROCEDURES}

\section{Prepare Measuring Tools}

This study prepares the following measuring tools: Scale estimate, to observe the outputs of the students from E-blogging; satisfaction scale with the e-learning environment; learning style scale for Felder-Silverman Learning Styles Model (Felder \& Silverman, 1988).

\section{Scale estimate}

Aims at measuring behavioral performance in designing and producing educational blogs skills, by using (blogger.com) one of management content style and specify the scale dimensions and items; backgrounds, theoretical attitudes, and literature reviews (Collison et al., 2006; Hsu, 2011, 2012), associated to E-blogs, were accessed, and get benefits to design observation card. This card enrolled 4 sub-skills, every skill covers a number of behavioral performance that students should carry out sequentially, and with the specific accuracy to get the behavioral performance accomplishment mark, these skills are:

- Designing the general shape for the blog (design the user interface) with (8) behavioral performances that can be observed.

- Designing (patterns, drawings, videos, and links) in educational blog, considering the technical measurements with (21) behavioral performances that can be observed.

- Accomplishing scientific standards of designing educational blog with (6) behavioral performances that can be observed.

- Accomplishing the activation of educational blog sides, with (5) behavioral performance that can be observed.

The observation card was showed to a group of information technology specialists to specify if it is appropriate for the purpose of the current research. Also, it applied to the survey sample from students learned this course without the main research sample, the observation card internal validity was checked by calculating correlation coefficient matrix between its dimensions and its total degree, the correlation coefficient values rang between (0.783-0.319) and the correlation coefficient previous values significance at level (0.01); demonstrate how far the internal consistency of the observation card construction. To measure the card reliability, the researcher observed the survey sample students' performance during carrying out the assigned tasks of design and produce the educational blog by using the required tools; then another college from educational technology section who has experience in designing educational blog, and production tools, observed the same sample performance and measured the reliability through Cooper equation to measure similarities and differences rate among the observers, the values agreement rates ranged between $(90.1 \%: 83.6 \%)$ this indicates the validity of observation card, hence the observation card became ready in its final shape, abstract (4) and valid to apply the current research purpose. 
Table 1. Correlation coefficient matrix for e-learning environment satisfaction dimension scale

\begin{tabular}{|c|c|c|c|c|c|c|}
\hline Scale cores & $\begin{array}{l}\text { System using } \\
\text { facility }\end{array}$ & $\begin{array}{l}\text { System } \\
\text { function }\end{array}$ & $\begin{array}{c}\text { Interactions } \\
\text { (teachers and } \\
\text { students support) }\end{array}$ & $\begin{array}{c}\text { Feedback } \\
\text { provision } \\
\text { synchronizing }\end{array}$ & $\begin{array}{c}\text { General } \\
\text { satisfaction }\end{array}$ & $\begin{array}{c}\text { Total degree } \\
\text { of scale }\end{array}$ \\
\hline $\begin{array}{l}\text { System using facility } \\
\text { satisfaction }\end{array}$ & - & & & & & \\
\hline $\begin{array}{l}\text { System functions } \\
\text { satisfaction }\end{array}$ & $0.451^{\star \star}$ & - & & & & \\
\hline $\begin{array}{l}\text { Interaction satisfaction } \\
\text { (teacher, students } \\
\text { support) }\end{array}$ & $0.615^{\star \star}$ & $0.574^{\star \star}$ & - & & & \\
\hline $\begin{array}{l}\text { Feedback provision } \\
\text { synchronizing }\end{array}$ & $0.487^{\star \star}$ & $0.694^{\star \star}$ & $0.629^{\star *}$ & - & & \\
\hline $\begin{array}{l}\text { Learning environment } \\
\text { satisfaction }\end{array}$ & $0.549^{\star \star}$ & $0.652^{\star \star}$ & $0.694^{\star \star}$ & $0.718^{\star \star}$ & - & \\
\hline Total degree of scale & $0.627^{\star \star}$ & $0.735^{\star \star}$ & $0.720^{\star \star}$ & $0.763^{* *}$ & $0.778^{\star \star}$ & - \\
\hline
\end{tabular}

\section{E-learning environment satisfaction scale}

It aims at measuring students' E-learning environment satisfaction. To specify the scale dimensions, terms, backgrounds, theoretical attitudes, and various concepts in E-leaning field. E-learning environment satisfaction, were accessed, and to benefit from some literature reviews included used tools and measurements (Chang, 2011; Harrati, Bouchrika, Tari, \& Ladjailia, 2016; Harvey, Parahoo, \& Santally, 2017; Raspopovic \& Jankulovic, 2017; Violante \& Vezzetti, 2015; Virtanen et al., 2017; Wu, Tennyson \& Hsia, 2010). This scale enrolled 36 phrases presented in 5 dimensions: The facility of using the systems, System functions, Interactions, Feedback provision synchronism, Overall satisfaction with learning environment.

The e-learning environment satisfaction scale was viewed to the judges of the tools to specify its appropriateness for the purpose of the recent research, its formatting accuracy, and it's covering to the representative cores, and doing the required editions in the light of the judge's views. Also the researcher applied the scale on the survey sample from students who learned the course with this method in the first semester without the research sample, then the researcher calculates the scale internal validity of correlation coefficient matrix between its phrases degree and the total degree points, the correlation coefficient values ranged between $(0.396-0.837)$ this indicates the phrases correlation range of the scale with each other and with the total degree, the previous correlation coefficient values is significance level at $(0.01)$ and prove the scale internal constructive consistency range also calculating the correlations coefficient between the scale dimension and its total mark to reveal the internal consistency components, viewed in Table 1.

The previous values of correlation coefficient is an indicator for scale cores and phrases validity of measuring the e-learning environment satisfaction to measure the scale reliability, the researcher evaluated the survey sample students on this scale then counted Cronbach's Alpha correlation value that reached (0.718), this value is appropriate for the recent research, hence the scale satisfaction became in its final shape, abstract (5), valid to apply on the recent study.

\section{Learning style scale}

The researcher used “Felder \& Silverman Learning Styles Model" which developed before (Felder \& Silverman, 1988). The scale consists of 44 dimensions: 11 items for every dimension. The students classified at this scale through bipolar four dimensions; (active - reflective), (sensual - initiative), (visual - oral), (sequential - comprehensive). There are two choices for each item (A-B), the first choice represents the first trend, and the second choice represents the second trend of the dimension; and give mark (1) with (A) choice and (-1) with (B) choice. Every dimension measured by eleven items putted in the questionnaire periodically, and the questionnaire gives four marks (it has no Fullmark) through it, we could distribute students according to the used learning style and students classified according to this model as following: If the student got a mark between ( $3 \&-3)$, it means he does not prefer any of two dimensions style; If the student got a mark between $(-5 \&-7)$ or $(+5 \&+7)$, it means he prefer any of two dimensions style with moderate degree; If the student got a mark between $(-9 \&-11)$ or $(+9 \&+11)$, it means that he prefer any of two dimensions strongly.

Numerous studies and researches are done to verify the validity and reliability of learning style indicator questionnaire on different samples from university students, and from many cultures and various societies. So the questionnaire was translated to six languages, and the results of those studies showed approximate values for the 


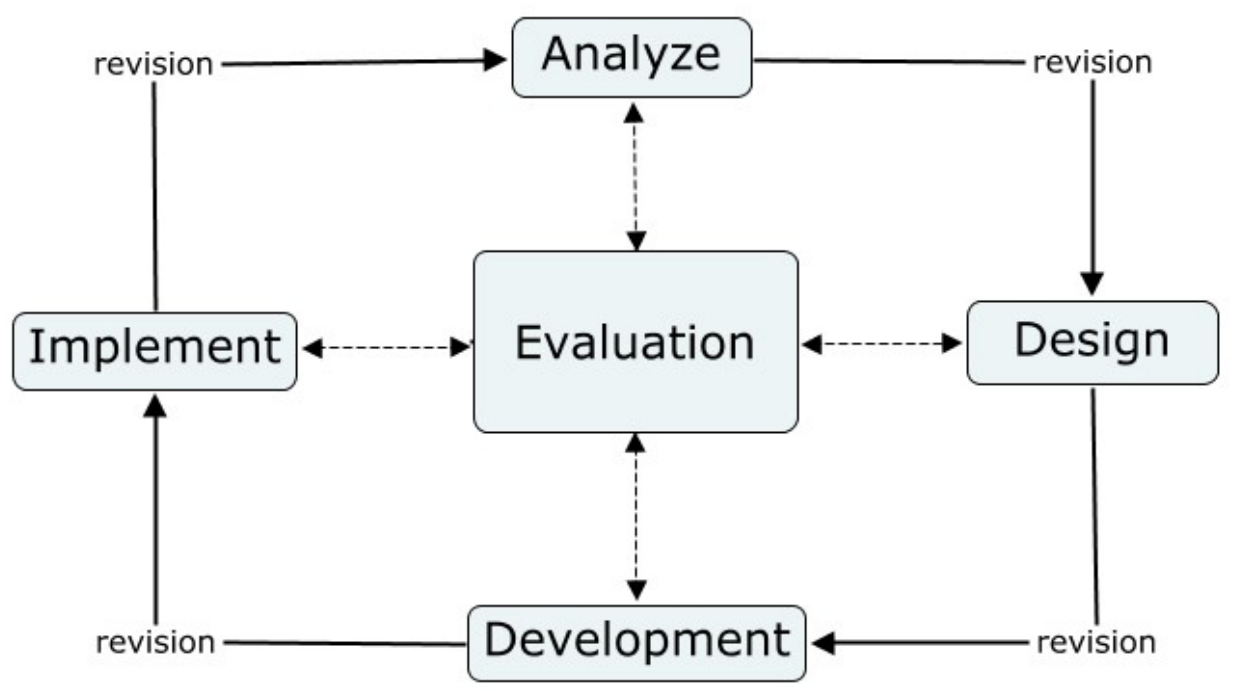

Figure 2. ADDIE instructional design model

validity and reliability of the model from a study to another (Filippidis \& Tsoukalas, 2009). In Zywno (2003), the sample consisted of (577) university students; the results verified that the scale has a high reliability degree using the reapplying method whereas Pearson correlation coefficient values are between $(0.507 \& 0.683)$ and all of them were significant statistically. Litzinger et al. (2007) investigated the reliability and validity of learning style scale where the internal consistency coefficient for the four learning styles items enrolled by the scale was extracted.

Also, at Arab environment, Abu-Hashem (2010) measured the construct validity for Felder and Silverman learning style model on a sample of university students, and translated the questionnaire to Arabic language. AbuAuad and Noafl (2012) measured the validity and reliability significant for Felder- Solomn scale of learning style, while it was translated to Arabic at Jordanian environment on a survey sampling from Jordanian university students amount to (455) students, and it found that the scale has internal consistency coefficient for the four measurement items.

\section{Design and Development of the Research Experimental Treatment}

The author designed the experimental treatment and developed it by using (ADDIE) model. The ADDIE model is a systematic instructional design model consisting of five phases: (1) Analysis, (2) Design, (3) Development, (4) Implementation, and (5) Evaluation (Branch, 2009). It can be illustrated as shown in Figure 2.

A. Analysis phase: the following steps were taken:

- Determining the learners and their educational need: the learners are from the associated students to the general diploma program in Education Arab open university, KSA branch, which presents the academic programs to the students according to blended E-learning model, hence the students study $75 \%$ from learning time from a distance, and attending the remain learning time every 15 days face to face with the course teacher, and the description of the course requires student acquisition for practical skills and drills in course field through distance e-learning systems; Therefore, they are in a bad need to provide feedback for the students at appropriate time, and be constructive, motivating students, and communicate directly with evaluation standers and learning results for the required practical tasks.

- Determine the general aim: the experimental treatment aims to recognize the appropriate time to provide feedback (immediate - delayed), and the most appropriate technique to deliver to the learner in distance Elearning environment, and that came from its function impact on acquiring the design skills of educational E-blogs and satisfaction achievement with E-learning environment.

- Determine learning content: the content of technology learning course enrolled the following objectives: (1) The smart board and its uses in teaching; (2) Web techniques; (3) Broad cast techniques; (4) mobile - learning techniques and the design and production skills of educational E-blogging using the necessary software considered as the practical application of this course. 


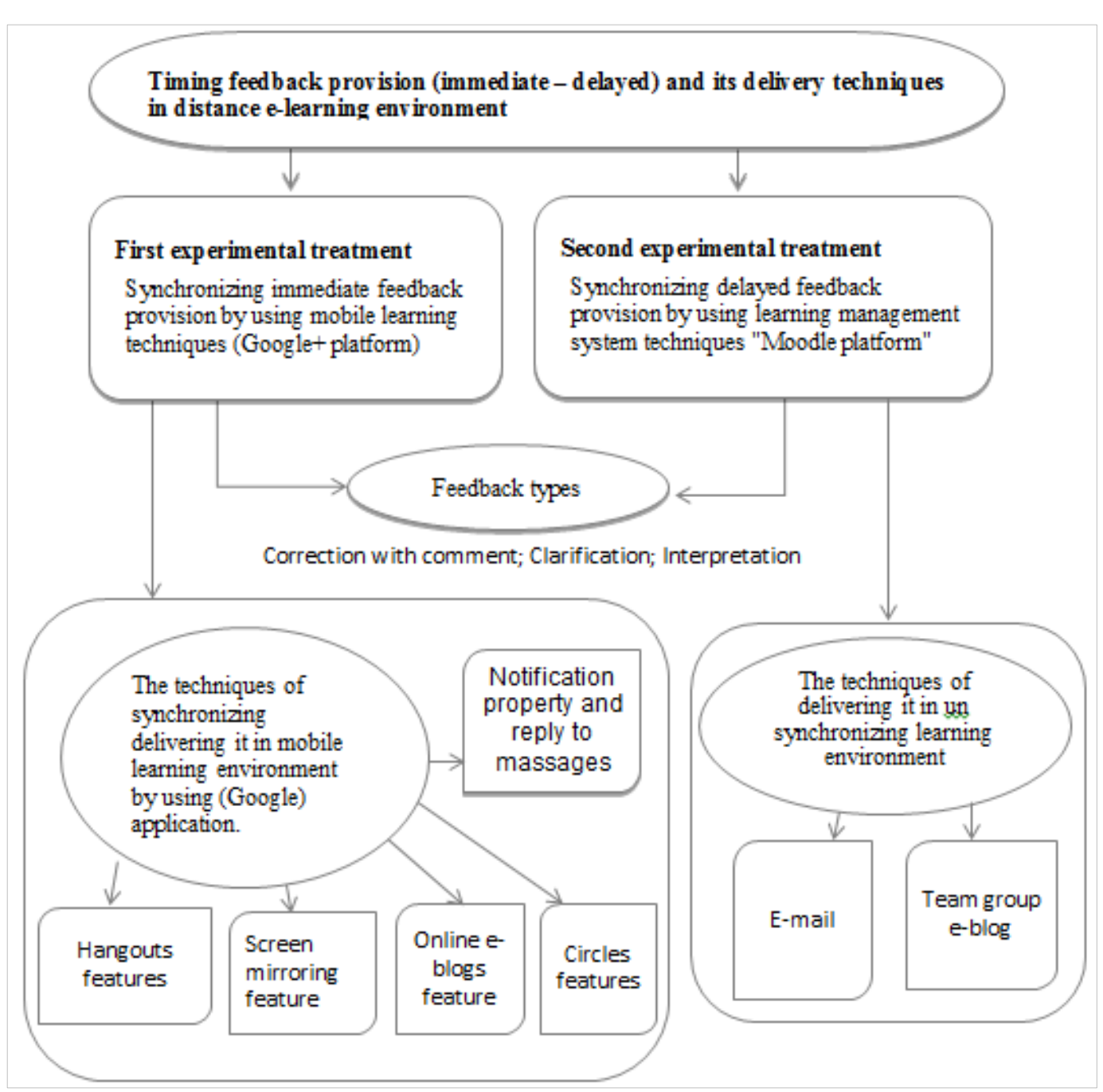

Figure 3. Design of the research experimental treatment

\section{B. Design phase:}

In this phase, the content of e- learning designed, developed, and put on the management system, this content uses distance-learning style for both the experimental groups and the only difference between them is presented in feedback provision time and its presentation method (immediate-delayed). Figure 3 explain that.

\section{- The first experimental treatment:}

It was developed to provide immediate feedback by using mobile-learning techniques (Google+) as the following; regardless learning styles, the learner receives in this experimental group an immediate feedback for educational tasks inquiries, performed; immediately after finishing performing every stage in it or performing it totally, this would be (individual or team work), (written text or auditory voice call/ note or multimedia SMS) of $(\mathrm{Google}+)$ tools through the experimental treatment across tablets, and smart phones, that enabled experimental groups learner the interactions between them and the course teacher and among themselves shortly at the moment of inquiry or the moment of delivering the task, to check it and give the appropriate feedback through employing the following tools:

- Circles establishment: This tool enable the course teacher to collect students in one group connected through a relationship of studying the course, accomplish the tasks, and the assigned practical tasks from a distance, this enable them to share the relative content and common interests with the teacher of the course in addition to solve the problem that may encounter them

- Hangouts: Making a video call: this tool (hangouts) enabled learners of experimental group to speak live (individual- team work) through voice and live image or sharing files, and editing them together or mirroring their (mobile screen or computers screen) with the course teacher or with their colleges, also this feature enable to collect group of friends have problem in performing a task or a procedure of the required 
task procedures to make a conference call through video chat face to face with text, images, to find solution for the problems that may confront them during performing the practical task.

- E-blogs: (Google+) e-blogs consider places in which individuals get together, talking about common interests; this feature enabled the course teacher and learners from a distance to perform an immediate participation, and to see others' participation, also to see their works, and the accomplished steps they take in carrying out their assigned practical tasks. It can be a participation theory text or images or videos or links or sites bookmarks, also the participation can be whether individual with person or through team work for a circle of the other established circles, hence the content will appear in their e-blog page.

- SMS short massages: This tool enabled learners of experimental group to receive immediate notifications for every action, course teacher makes or any other learner in the same circle, also every comment added, and every conversation done, all across SMS. in this experimental treatment those used tools helped the course teacher to provide immediate feedback for every activity or task performed instantly, and just after finishing the task, all viewed immediately on the course teacher cell phone, and the other learners of this course, who participate in the same circle, hence all links of blogs, produced by the learner, are in one circle, just when the learner add any edition in his blog, this edition appears directly to all other learners who are participating in this circle, and of course also for the course teacher, who by his turn give immediate feedback . also screen mirroring enabled the course teacher to follow the learner during his work on the blog in every step he takes from a distance, the course teacher can see it, and add immediate postscripts, this allow the course teacher to provide the immediate feedback on the tasks inquiries for every learner alone in personal or for a group of learners together.

\section{- The second experimental treatment:}

It was developed to provide delayed feedback by using learning management system techniques "Moodle". Regardless of learning style, the learner received in this experimental group "delayed feedback" which presented after learner response for learning task for a period of time which may take from an hour to 48 hours from sending the inquiry; that may be individual or teamwork ; (verbal written style) through employing learning management system tools that available to him across electronic gates of Arab open university, and that allows the students to study their courses from a distance by electronic method; the following tools are used in this experimental treatment which provide by the used learning management system:

- The E-mail of learning management system: to provide the learner with feedback after finishing any stage of Eblogs designing stages, or for whom have inquiry around the design and production steps for the required task.

- Cooperative blogs for learning management system: through learning management system a blog was established, so the students could discuss the problems they faced in studying the course or during fulfillment the required tasks and assignments, and the course teacher respond on it. This tool is used to provide (written) feedback to respond on the student inquiries and (delayed) whereas the course teacher $\log$ in to respond on the existed inquiries in the blog.

\section{Development phase:}

At the development phase, Researcher created and compiled the content assets described in the design phase. Create storyboards, Test material correction and procedures It. then reviews and revises the project according to the feedback.

\section{Application phase:}

The accomplishment of the study experimental treatments took ten academic learning weeks of the second semester, year 2013 - 2014; started from the second week of teaching and ended at the twelve week of teaching according to the timeline of teaching the course from a distance; hence the following are the procedures steps to accomplish experimental treatments of the study:

The Arab open university external students of educational general diploma program, studied the distance technology learning course by using the blended E-learning system through a period of time reached to 16 educational weeks, and through this period there are (5) tabled meetings face to face with the teacher of the course in the classroom.

- The student receives in his first face to face meeting: the course teaching book, time line for studying the course, and gets on the rest of learning activities with the course teacher across learning management system "Moodle" which available through university website gate.

- The course teacher in his first meeting face to face reviewed with the students the electronic content of the teaching course. It is about electronically views for the lectures using "power point views, PDF files" to be studied individually through learning management system. 
Table 2. The arithmetical means and standard deviation of distance applying grade for e-learning environment satisfaction scale and observation card for both of feedback types and learning styles

\begin{tabular}{|c|c|c|c|c|c|c|}
\hline \multirow[t]{2}{*}{ Feedback provision timing } & \multirow{2}{*}{$\begin{array}{l}\text { Learning } \\
\text { Style }\end{array}$} & \multirow[t]{2}{*}{ No } & \multicolumn{2}{|c|}{$\begin{array}{l}\text { Scale estimate } \\
\text { skills }\end{array}$} & \multicolumn{2}{|c|}{$\begin{array}{l}\text { e-learning environment } \\
\text { satisfaction }\end{array}$} \\
\hline & & & Mean & SD & Mean & SD \\
\hline \multirow{3}{*}{$\begin{array}{l}\text { "immediate" through m-learning } \\
\text { environment by using (Google+) } \\
\text { platform }\end{array}$} & Active & 19 & 112.26 & 4.44 & 164.63 & 8.59 \\
\hline & Reflective & 15 & 96.87 & 7.99 & 150.40 & 7.79 \\
\hline & Total & 34 & 105.47 & 9.91 & 158.35 & 10.83 \\
\hline \multirow{3}{*}{$\begin{array}{l}\text { "delayed" through learning } \\
\text { management system (Moodle) } \\
\text { platform }\end{array}$} & Active & 17 & 93.18 & 6.83 & 118.88 & 9.31 \\
\hline & Reflective & 16 & 88.50 & 15.85 & 111.50 & 13.36 \\
\hline & Total & 33 & 90.91 & 12.13 & 115.30 & 11.87 \\
\hline
\end{tabular}

- As a part of final evaluation for the educational technology course, required from distance learning student: distance practical drill on one of E-content management programs for the purpose of designing and producing educational e-blogs.

- Determine the activity (task): the students carry out the practical assignments and the required tasks which represented in designing educational blog in his specialization field and producing it using one of E-content management programs necessary to it.

- The experimental group students who received "immediate feedback" and their amount is 34 students, are asked to make a new account and participating in the course circle across M-learning platform which using (Google+), and that for immediate communication, and receiving feedback from the course teacher about their inquiries, and following them in their assignments accomplishing steps, while the experimental group students who received (delayed feedback) to communicate with the course teacher through the blog and university mail for university learning management system "Moodle".

- After learners finishing the specific period to deliver their assignments and projects they load it electronically for the teacher to evaluate it and monitoring grades.

\section{E. Evaluation phase:}

After finishing the experimental treatment accomplishment of the research, the following measurement tools are applied: "observation card, E-learning environment satisfaction scale, learning styles scale"; the posttest applied on the sample of the study; to confirm the impact of different timing feedback provision and its delivery techniques indifferent e-learning environment (immediate - delayed) on each of, the design and production skills of educational E-blogs and satisfaction with learners learning style.

\section{DISCUSSION AND INTERPRETATION}

\section{Descriptive Statistics of the Research Results}

The statistics treatment has been done for the points of post- applying results of the experimental groups' performance on every observation card for educational blog design skills, and satisfaction scale measurement of elearning environment for both of the two feedbacks with its two styles of learning and types, the result as Table 2 illustrate.

The previous Table 2 demonstrates the rise of students' mean scores of the experimental group who delivered immediate feedback across m-learning environment in their performance of e-learning blog design and production skills and e-learning environment satisfaction.

Also the table illustrates the rise of active students' mean scores whether those who delivered (immediate or delayed) feedback compared to reflective students in their performance of e-learning blogs design and production skills and e-learning environment satisfaction.

\section{Results Associated to Research Hypotheses Validity Test}

For the statistical analysis of the results, ANOVA Two-way analysis of variance and Descriptive statistics are utilized.

\section{The impact of feedback (immediate across "Google+" - delayed across "Moodle") on acquiring e-learning blogs design skills}

The first hypotheses of the research associated to the impact of feedback provision timing in distance e-learning various environment, regardless the following learning style on what precedes; "There is a significant statistical 
Table 3. The results of two ways variable analysis of feedback provision timing (immediate across m-learning environment techniques: delayed across learning management system techniques), impact on e-learning blogs design and production

\begin{tabular}{lccccc}
\hline Variable source & $\begin{array}{c}\text { Sum of } \\
\text { squares }\end{array}$ & df & $\begin{array}{c}\text { Means of } \\
\text { Squares }\end{array}$ & "F" value & $\begin{array}{c}\text { Significance } \\
\text { Indicator }\end{array}$ \\
\hline Among groups & 5718.14 & 3 & 1906.01 & 20.77 & 0.000 \\
\hline Timing feedback provision & 3132.25 & 1 & 3132.25 & 34.14 & 0.000 \\
\hline Learning style & 1674.50 & 1 & 1674.50 & 18.25 & 0.000 \\
\hline Time of feedback * learning style & 477.59 & 1 & 477.59 & 5.21 & 0.026 \\
\hline Error & 5779.59 & 63 & 91.744 & & \\
\hline Total & 658892.0 & 67 & & & \\
\hline
\end{tabular}

difference at level (0.05) between the mean scores of the experimental group students in their performance on the scale estimate for practical performance of the design and production of skills of E-blogging due to the different timing feedback provision (Immediate - delayed)" to test the validity of this hypotheses, the researcher used two ways variable analysis style for post-applying means of practical observation card for e-learning blogs design and production skills. The result as Table 3 illustrates.

Table 3 demonstrates that there is significance statistics differences between experimental groups averages which received immediate feedback across m-learning environment techniques and those who received delayed feedback across learning management system techniques. That is why there is a basic impact of feedback provision timing in various e-learning environment; and to investigate the direction of differences and in favor of which group will be;

Scheffe's test was applied, and the results revealed statistics significance differences on significance level (0.01); and it was in favor of the experimental group who delivered immediate feedback across m-learning environment, also the arithmetic means of immediate feedback across m-learning environment was (105.47) with standard deviation equal (9.91) in confrontation with arithmetic means (90.91) with standard deviation equal(12.13) of those students who delivered delayed feedback across learning management system techniques, hence the first hypotheses of the research hypothesis was accepted.

\section{Results of basic impact for (active- reflective) learning style on acquiring skills of design and producing e-blogs}

The second hypotheses which associated to the impact of learning style -regardless timing of feedback provision-; states the following: "There is a significant statistical difference at level (0.05) between the mean scores of the student with active Learning style and the reflective students in their performance in practical scale estimate of the design and production Skills of E-blogging". To confirm the validity of this hypotheses go back to the previous Tables $2 \& 3$ where the results demonstrate the value of $(F)$ reached about (18.25) at significance indicator reached (0.01) ; this assure that there is a basic impact of learning style in students' mean scores in their practical performance on observation card practical performance for the skills of designing and producing e-blogs; which was in favor of the experimental group of active learning style who obtained the maximum Arithmetic's means that reached (102.72) compared to the Experimental group of reflective learning, as their arithmetic's means reached a value (92.86) that's why regardless. Feedback provision synchronizing type, practical active students obtained the highest score of E-learning blogging production and design by using required software, than reflective students that's why the second hypotheses of the research hypothesis was accepted.

\section{Results of the basic impact of interaction between timing feedback provision (immediate - delayed) and learning style (active - reflective) on the design skills acquisition of educational e-blogs}

The third hypothesis of the research hypotheses, which specialized with the effectiveness of interaction between the two types of timing feedback provision and between the two types of learning styles, states the following: "There is a significant statistical difference at level (0.05) between the mean scores of the of the experimental groups students in their practical performance for the production and design skills for the E- blogs returns to the impact of interaction between timing feedback provision (immediate - delayed) and learning style (active - reflective)".

To confirm the validity of this hypothesis should returns to the previous Tables 2, 3, where the results clarify that $(\mathrm{F})$ value that calculated for the impact of interaction between timing feedback provision and learning style reached to (5.21) at significant indicator (0.026) which less than (0.05), and that mean there is impact of interaction between timing feedback types and the learning style that used on students marks on their practical performance observation card for the design and production skills of e-blogs. To know the differences directions they returns to 
Table 4. The results of bipolar variance analysis for the impact of timing feedback provision (immediate - delayed) on satisfaction scale of e-learning environment

\begin{tabular}{lccccc}
\hline Variable source & $\begin{array}{c}\text { Sum of } \\
\text { squares }\end{array}$ & df & $\begin{array}{c}\text { Means of } \\
\text { Squares }\end{array}$ & "F" value & $\begin{array}{c}\text { Significance } \\
\text { Indicator }\end{array}$ \\
\hline Among groups & 5718.14 & 3 & 1106.90 & 111.61 & 0.000 \\
\hline Timing feedback provision & 3132.25 & 1 & 29779.06 & 300.47 & 0.000 \\
\hline Learning style & 1674.50 & 1 & 1941.48 & 19.59 & 0.000 \\
\hline Time of feedback * learning style & 477.59 & 1 & 194.96 & 1.96 & 0.166 \\
\hline Error & 5779.59 & 63 & 99.11 & & \\
\hline Total & 658892.0 & 67 & & & \\
\hline
\end{tabular}

"Scheffe" Test, and with reviewing the previous Table 2 the following is illustrates: the rise of the mean scores of the active students with immediate feedback types across mobile-learning environment which its value reached to (112.26) with standard deviation (4.44), while the mean scores of the reflective students with immediate feedback type reached to (69.87) with standard deviation (7.99). Also the previous Table 2 reveals that the experimental group with active practical learning style got mean scores (93.18) with standard deviation (6.83) higher than experimental group with reflective learning (88.50) with standard deviation (15.85) and that in delayed feedback type. All that prove there is impact of interaction between timing feedback provision (immediate - delayed) in both two different environments of e-learning and learning style (active - reflective) on the acquisition of the design and production skills of educational e-blogs, and this interaction is in favor of the experimental group students with active learning style and who received immediate feedback through mobile e-learning environment; due to that the third hypothesis of the research was accepted.

\section{Results of the basic impact for timing feedback provision (immediate - delayed) on satisfaction with e-learning environment}

The fourth hypothesis which associated with the impact of timing feedback provision from distance e-learning different environments - regardless the learning style - states the following: "There is a significant statistical difference at level (0.05) between the mean scores of the experimental groups students in their performance on satisfaction scale about E-learning environment returns to different timing feedback provision (immediate delayed)".To test the validity of the hypothesis, the researcher used bipolar variance analysis style for the post applying scores of statistical scale about e-learning environment, the results viewed as Table 4 illustrated.

Table 4 illustrate a significant statistical different between the mean scores of the experimental group that received immediate feedback through techniques of mobile e-learning environments. The other group that received delayed feedback through techniques of e-learning management system, that means there is a basic impact of timing feedback synchronization of feedback in different e-learning environments in the experimental groups' performance on satisfaction scale with e-learning environment and to investigate the difference direction and in favor of which group; "scheffe" Test is used and the results revealed that there is a significant statistical difference at significance level reached (0.01) it was in favor of the experimental group which received immediate feedback through mobile e-learning environment (google+) that got arithmetic means reached to (157.5) versus the experimental group that received delayed feedback "moodle" and got in its performance on the scale with arithmetic mean reached (115.19), so the validity of the fourth hypothesis from research hypotheses was accepted.

\section{Basic impact results for learning style (active - reflective) on satisfaction with e-learning environment}

The fifth hypothesis of the research hypotheses associated to the impact of learning style states on the following: "There is a significant statistical difference at level (0.05) between the mean scores of the experimental groups students with active learning style and the reflective students in their performance on satisfaction scale of Elearning environment". To confirm the validity of this hypothesis we return to Tables $2 \& 4$ where illustrated from the results that $(\mathrm{F})$ value reached (19.59) at significant indicator reached (0.01) which means that there is a basic impact of learning style on students' performance marks on satisfaction scale about e-learning environment in favor of the experimental group with the highest average, they are active learning style students which their arithmetic mean in performance on satisfaction scale about e-learning environment reached the value (141.76) comparing with the reflective experimental group students, which their arithmetic mean in performance reached the value (130.95). So the fifth hypothesis from research hypotheses was accepted. 


\section{Impact results on interaction between two types of feedback provision (immediate - delayed) and learning style (active - reflective) on satisfaction with e-learning environment}

The sixth hypothesis of the research hypotheses that associated with the impact of interaction between the two used types of feedback, and the two used learning styles, states the following: "There is a significant statistical difference at level (0.05) between the mean scores of the of the experimental groups students in their performance on satisfaction scale about E-learning environment returns to the impact of interaction between timing feedback provision (Immediate - Delayed) and learning style (Active - Reflective)". To confirm the validity of the hypothesis should back to the two previous Tables 2, 4, where the results illustrate that (F) calculated value for the impact of interaction between timing feedback provision and learning styles reached (1.976) at significant indicator reached (0.166) and it is lower than table value; that means there is no impact of interaction between timing feedback provision and the used learning style on the students' performance scores on satisfaction scale with e-learning environment. Hence the sixth hypothesis of the research hypotheses was declined.

\section{The Interpretation of Research Result}

The test result validity of the research hypothesis illustration as the following:

\section{Results associated to the impact of feedback provision timing (immediate across mobile - learning management system techniques) on acquiring skills of E-blogs design and production, and satisfaction with e-learning environment}

The results of the recent research referred to the differences of statistics significance between means scores of experimental groups who received immediate feedback in acquiring skills of producing and designing e-blogging and e-learning environment satisfaction. Due to the basic impact of feedback provision time (immediate across Mobile learning environment techniques - delayed across learning management system techniques) that's why the results were in favor of Experimental group (1 \& 3) that received immediate feedback across M-learning environment techniques compared to the Experimental group $(4 \& 2)$ which received delayed feedback across learning management techniques. This result can be illustrated as the following:

The employment of Experimental treatment of synchronizing connecting tools across tablets or across (Google + ) application, smart phones to present the immediate feedbacks, provided the student in this experimental groups with the interactions between student and the course teacher immediately and the moment of the inquiry, or the moment of delivering the task (sharing the blog link) to see it and receive the suitable feedback, immediately just after finishing any step or task of the practical tasks necessary to produce the required educational activity of designing and producing the E-blogging for their specialty field by using blogger services, at the same time without delay according to their actual needs. Besides the actual existence group students at the same time and at any place through their mobiles, helped them to exchange ideas through direct text message and conversation, voice calls and to solve the problem that confront them during designing and producing the educational tasks, students complete and follow their discussion at the same time with the course teacher across conference call (hangout) increased their ability to concentrate and follow and then accomplish their practical tasks. screen mirroring task also enabled the course teacher to follow the student and watch learner during working on the E-blogging in every step he makes from a distance and to give immediate post scripts of works, also enable the course teacher to deliver immediate feedback for the tasks and inquiries for every student alone in personal, or to a group of learner together in group, also blogger allowed the course teacher and distance learner to participate immediately (text - images video clips and sites links) and see other's participants, work, and every step accomplished in implying their assigned practical tasks . also replying to notification across SMS feature enabled experimental group learners to receive immediate notifications for every participation by the teacher course or other learners at the course circle, also every comment added, Or conversation or a call made all through SMS, M- learning platform used in experimental group, distinguished with saving dialogue text discussion for all notices provided by the course teacher for learners during the stages of the designing and producing the E-learning task, so enabling all to review the feedback content at any moment, also the facility of practicing learning activity with smart phones, tablets reduced the required time for the course teacher to provide the learners of experimental group according to this type with fast and accurate postscripts (Taylor, Schugar, \& Penny, 2014).

We can say: the tools and features distinguish this experiential treatment helped to deliver immediate feedback, for every task or activity done by the learner or just after the learner edit his blog or finish making any step of the learning task, viewed at once on the course teacher phone and other learners of this course and participating at the same circle phones and then the teacher does his turn in providing immediate feedback which make learners of the experimental groups achieve results more positive in acquiring skills of the design and production of E-blog and due to the immediate feedback was always fast and at the appropriate time and aims at developing students work 
papers, and helped the learners to carry out his task to the fullest, motivating and illustrated whatever the learner does. That's why the experimental groups students who received immediate feedback get more satisfied with Elearning environment than those who received delayed feedback within 48 hours, after asking for it across email or unsynchronized discussion forum through learning management system platform. This result agrees with other previous literature reviews' results, thus Xu study (2010) clarified that most students of this study sample (96\%) percentage confirmed that immediate feedback delivered by their course teacher across tablets or lab-tops was too useful to understand the content and improve their self-motivation for learning, and provided them with interactions and participation with the teacher for the discussion performed online. Also this studies (Nortcliffe \& Middleton, 2011) agree with "Nortcliffe" that revealed that using smart phones was more appropriate than any other various technique, helped the teacher to manage his time and Exceptional effort associated to submitting postscripts and put marks on students works and tasks, as a result, the study sample revealed that the students excited with a good motivate experience of using their personal smart phones to receive feedback and replies to the tasks which contribute in improving the quality of feedback and its impact on learning, Also those studies agree with Hwang and Chang (2011).

Studies results which revealed that formative Evaluation entrance based on M-learning environmental was very helpful and useful to improve their academic achievement and better their educational achievement, and develop their attitudes toward learning. Also those studies agree with Huang and his colleges students (2008) that revealed that M-learning systems facilitate synchronizing learning through enabling students receive lessons probably and effectively through various and wide groups of tools by using wireless devices, finally also agree with Chen and his colleges studies (Chen, Chang, \& Wang, 2008).

That revealed that mobile phones immediate calling features affected learning process and interactions among students received materials and browsing functions in cell phone, enabled the users to receive information data in the appropriate time. The recent current study results with a conclusion of previous literature reviews shown above, clarify that M-learning environment is an effective tool of immediate feedback provision, and it has the ability to enhance academic achievement and improve students' learning outcomes and achieving environment satisfaction. These results are consistent with the results of previous studies (DeLucenay, Conn, \& Corigliano, 2017; Lefevre, \& Cox, 2017).

\section{Results related to the impact of two learning styles (active - reflective) on each of acquiring the design and production skills of e-blogging and satisfaction with e-learning environment}

The results illustrate that there is a significant statistical difference at level (0.01) between the mean scores of active learning style students and the reflective students in their performance on practical performance observation card for the design and production of e-blogging and satisfaction with e-learning environment; the researcher explain that by the following:

Active style students prefer learning through experimentation and team work, and they tend to obtain and understand the information through doing applicable process, and through teamwork, and that agree with the used experimental treatment type. Where the activity exercise of practical learning by designing and producing the e-blogging and team work learning, where the actual presence for the students at the same time, anywhere, anytime, and across their mobile devices or across other wireless devices, which help them to exchange ideas and immediate conversations whether text or voiced for solving problems that encountered them during the design and production process of educational task. The students completing their conversation and all of them are following it at the same time through communication device (hangouts). Moreover, their employment to the blogs which enabled them to do immediate participation and seeing the others participations and their projects and the accomplished tasks in fulfillment their practical tasks which assigned to them. Hence, we could say that there is harmony between the introduced experimental treatment style and the learning style for these experimental groups; the condition that made them achieve to better results in each of the practical performance of the design and production skills of e-blogging and satisfaction with e-learning environments, from those students who tends to abstract thinking, and prefer thinking quietly first, also they prefer individual word which agreed with delayed feedback type that provided to them across asynchronous blog in learning management system.

This result agreed with various studies results which confirm the interactions between the teacher of the course and the students, and among students themselves, were important to the learning process. Also the interaction at appropriate time between the teacher and the learner was definite in strengthen/ reinforcement student learning, and the immediate and quick feedback from the teacher at appropriate time are essential key to achieve learners satisfaction about e-learning environment (Harrati et al., 2016; Harvey et al., 2017; Raspopovic \& Jankulovic, 2017; Violante \& Vezzetti, 2015; Virtanen et al., 2017; Wu et al., 2010). 


\section{The results associated to the impact of interaction between timing feedback provision (immediate - delayed), and the two learning styles (active - reflective) on each of the design and production acquiring skills of e-blogging and satisfaction with e-learning environment}

The results of the research indicates that there is a significant statistical difference at level (0.05) between the mean scores of the students sample of the research in their performance on practical performance observation card for the design and production skills of e-blogging, due to the impact of interaction between timing feedback provision (immediate across techniques of mobile e-learning environment -delayed across techniques of e-learning management system "Moodle") and learning style (active - reflective) which confirm the impact of interaction between timing feedback provision (immediate - delayed) and learning style (active - reflective) on acquiring the design and production skills of e-blogging, this result may explained as the characteristics of active style students agreed with immediate feedback provision across mobile e-learning environment. They prefer the active learning, and prefer learning in groups and in a team work, that allowed by the experimental treatment by providing synchronous communicated environment across mobile devices, and receiving immediate feedback which helped them to exchange ideas or immediate text conversations or the voiced one, to solve the problem that encounter them during the designing of educational task and producing it. So the students could acquire the design and production skills of e-blogs effectively.

While the results indicates that there in not a significant statistical difference at level (0.05) between the mean scores of the students sample of the research in their performance in satisfaction scale with e-learning environment returns to the impact of interaction between timing feedback provision (immediate - delayed) and learning style (active - reflective); that means there is no impact of interaction between timing feedback provision and the used learning style on students' scores in their performance on satisfaction scale with e-learning environment.

We could explain this result as regardless the learning style, the first and third experimental groups which received immediate feedback through techniques of mobile learning environment supplied approximated results and high satisfaction degrees about immediate feedback type and its facility receive across wireless communication techniques, which led to no existence of impact for the interaction between timing feedback and learning style on satisfaction scale of e-learning environment compared with the second and fourth experimental groups which received delayed feedback across learning management system "Moodle".

\section{STUDY RECOMMENDATIONS AND PROPOSALS}

In the light of the results that the recent research and previous literature reviews pointed to (DeLucenay et al., 2017; Harrati et al., 2016; Harvey et al., 2017; Lefevre \& Cox, 2017; Raspopovic \& Jankulovic, 2017; Violante \& Vezzetti, 2015; Virtanen et al., 2017), and research's projects included in the folds, the researcher presented some recommendations and educational applications to benefit from it as a practical applications when designing Elearning contents as the following:

(1) Direct active students to synchronizing e-learning type, to achieve the maximum benefit from receiving immediate feedback during their studying to e-courses.

(2) Employing M-learning environments because it saves effective tools for feedback provision as using smart personal cell phones to deliver feedbacks for students from a distance and fast reply to their tasks contribution in improving the quality of feedback and its impact on learning as well as achieving satisfaction through E-learning from a distance.

(3) M-learning system should be employed to facilitate synchronizing learning as receiving learning subject and data transfer, browsing functions, SMS in cell phones help users to reach to feedback information at the appropriate time.

(4) The necessity of holding training courses for teaching staff members, and E-course designers to train them on the various strategies of perfect and effective feedback provision in E-learning environments from a distance as training them on provision methods with wireless synchronizing communication techniques, especially if we considered that feedback provision should be fast and immediate and at the appropriate time and more personalized for the learner.

The study proposed doing more researches to compare the impact of the different types of feedback contents and its receiving methods on improving some of learning outcomes for learners, of which:

(1) Doing a study to reveal distance significance of feedback (specify the mistake and correct it give the correct answer) (giving deeply detailed information or fast and brief information) on learning outcomes for learners.

(2) The impact of interactions between the feedback provision (individual - teamwork) specialty and learning style (active - reflective) in synchronizing E-learning environment on learning outcomes for learners. 
(3) The impact of interactions between feedback types (brief text-detailed multimedia) in synchronizing elearning environment and learning style (visual- verbal style) on the outcomes of the learners through learning process.

\section{REFERENCES}

Abu-Auad, F. M., \& Noafl, M. B. (2012). Validity and reliability significant learning styles scale for -Felder, Soloman. and the degree of preference for Jordan universities students. Demascus University Journal, 28(1), 483-445.

Abu-Hashem, E. M. (2010). Constructive validity of Felder and Silverman learning style model for university students. King Saud University. Journal of King Saud university for educational sciences and Islamic. (35), 1-24.

Afifi, M. K., \& Alamri, S. S. (2014). Effective principles in designing e-course in light of learning theories. Turkish Online Journal of Distance Education, 15(1). https:/ / doi.org/10.17718/tojde.43806

Branch, R. M. (2009). Instructional design: The ADDIE approach (Vol. 722). Springer Science \& Business Media. https:/ / doi.org/10.1007/978-0-387-09506-6

Chang, N. (2011). Pre-Service Teachers' Views: How Did E-Feedback through Assessment Facilitate Their Learning? Journal of the Scholarship of Teaching and Learning, 11(2), 16-33.

Chen, G. D., Chang, C. K., \& Wang, C. Y. (2008). Ubiquitous learning website: Scaffold learners by mobile devices with information-aware techniques. Computers $\mathcal{E}$ Education, 50(1), 77-90. https:/ / doi.org/10.1016/j.compedu.2006.03.004

Collison, S., Davis, C. J., Heilemann, M., Oxton, J., Powers, D., Rutter, R., \& Sherry, P. (2006). Blog Design Solutions. Friends of ED.

DeLucenay, A. J., Conn, K. M., \& Corigliano, A. (2017). An evaluation of the impact of immediate compared to delayed feedback on the development of counselling skills in pharmacy students. Pharmacy Education, 17.

Evans, C., \& Waring, M. (2011). Student teacher assessment feedback preferences: The influence of cognitive styles and gender. Learning and Individual Differences, 21(3), 271-280. https:/ / doi.org/10.1016/j.lindif.2010.11.011

Felder, R. M., \& Silverman, L. K. (1988). Learning and teaching styles in engineering education. Engineering education, 78(7), 674-681.

Filippidis, S. K., \&Tsoukalas, I. A. (2009). On the use of adaptive instructional images based on the sequentialglobal dimension of the Felder-Silverman learning style theory. Interactive Learning Environments, 17(2), 135150. https:/ / doi.org/10.1080/10494820701869524

Freney, M. H. P., \& Wood, D. (2008). The Delivery and Management of Feedback and Assessment in an E-learning Environment. The international journal of learning, 15(2), 169-178. https://doi.org/10.18848/14479494/CGP/v15i02/45607

Harrati, N., Bouchrika, I., Tari, A., \& Ladjailia, A. (2016). Exploring user satisfaction for e-learning systems via usage-based metrics and system usability scale analysis. Computers in Human Behavior, 61, 463-471. https://doi.org/10.1016/j.chb.2016.03.051

Harvey, H. L., Parahoo, S., \& Santally, M. (2017). Should gender differences be considered when assessing student satisfaction in the online learning environment for millennials? Higher Education Quarterly, 71(2), 141-158. https:/ / doi.org/10.1111/hequ.12116

Hsu, C. C. (2011). Factors affecting webpage's visual interface design and style. Procedia Computer Science, 3, $1315-$ 1320. https:// doi.org/10.1016/j.procs.2011.01.009

Hsu, C. C. (2012). Evaluation criteria for blog design and analysis of causal relationships using factor analysis and dematel. Expert Systems with Applications, 39(1), 187-193. https:/ / doi.org/10.1016/j.eswa.2011.07.006

Huang, Y. M., Kuo, Y. H., Lin, Y. T., \& Cheng, S. C. (2008). Toward interactive mobile synchronous learning environment with context-awareness service. Computers $\mathcal{E}$ Education, 51(3), 1205-1226. https:/ / doi.org/10.1016/j.compedu.2007.11.009

Hwang, G. J., \& Chang, H. F. (2011). A formative assessment-based mobile learning approach to improving the learning attitudes and achievements of students. Computers $\mathcal{E}$ Education, 56(4), 1023-1031. https:// doi.org/10.1016/j.compedu.2010.12.002

Khamis, M. A. (2009). E- Supporting. Egypt Educational technology, 19(2), 1-2.

Lefevre, D., \& Cox, B. (2017). Delayed instructional feedback may be more effective, but is this contrary to learners' preferences?. British Journal of Educational Technology, 48(6), 1357-1367. https:/ / doi.org/10.1111/bjet.12495

Litzinger, T. A., Lee, S. H., Wise, J. C., \& Felder, R. M. (2007). A psychometric study of the index of learning styles $\odot$. Journal of Engineering Education, 96(4), 309-319. https:/ / doi.org/10.1002/j.2168-9830.2007.tb00941.x 
Narciss, S. (2013). Designing and Evaluating Tutoring Feedback Strategies for digital learning environments on the basis of the Interactive Tutoring Feedback Model. Digital Education Review, (23), 7-26.

Narciss, S., Sosnovsky, S., Schnaubert, L., Andrès, E., Eichelmann, A., Goguadze, G., \& Melis, E. (2014). Exploring feedback and student characteristics relevant for personalizing feedback strategies. Computers $\mathcal{E}$ Education, 71, 56-76. https:/ / doi.org/10.1016/j.compedu.2013.09.011

Nortcliffe, A., \& Middleton, A. (2011). Smartphone feedback: Using an iPhone to improve the distribution of audio feedback. International Journal of Electrical Engineering Education, 48(3), 280-293. https:/ / doi.org/10.7227/IJEEE.48.3.6

Raspopovic, M., \& Jankulovic, A. (2017). Performance measurement of e-learning using student satisfaction analysis. Information Systems Frontiers, 19(4), 869-880. https:/ / doi.org/10.1007/s10796-016-9636-Z

Sorensen, P. (2008). Feedback and Assessment. Malaysian Journal of Distance Education, 10(2), 85-105.

Taylor, P., Schugar, J., \& Penny, C. (2014, March). Reinventing the Classroom with Google+. In Society for Information Technology \& Teacher Education International Conference (Vol. 2014, No. 1, pp. 1352-1353).

Vandewaetere, M., Desmet, P., \& Clarebout, G. (2011). The contribution of learner characteristics in the development of computer-based adaptive learning environments. Computers in Human Behavior, 27(1), 118130. https:/ / doi.org/10.1016/j.chb.2010.07.038

Violante, M. G., \& Vezzetti, E. (2015). Virtual interactive e-learning application: An evaluation of the student satisfaction. Computer Applications in Engineering Education, 23(1), 72-91. https:/ / doi.org/10.1002/cae.21580

Virtanen, M. A., Kääriäinen, M., Liikanen, E., \& Haavisto, E. (2017). The comparison of students' satisfaction between ubiquitous and web-based learning environments. Education and Information Technologies, 22(5), 2565-2581. https://doi.org/10.1007/s10639-016-9561-2

Wu, J. H., Tennyson, R. D., \& Hsia, T. L. (2010). A study of student satisfaction in a blended e-learning system environment. Computers \& Education, 55(1), 155-164. https:/ / doi.org/10.1016/j.compedu.2009.12.012

Xu, Y. (2010). Examining the Effects of Digital Feedback on Student Engagement and Achievement. Journal of Educational Computing Research, 43(3), 275-291. https:/ / doi.org/10.2190/EC.43.3.a

Zywno, M. S. (2003, June). A contribution to validation of score meaning for Felder-Soloman's index of learning styles. American Society for Engineering Education annual conference E exposition, 119, 1-5.

\section{http://www.ejmste.com}

